\title{
Based on the foundation, four regressions, escort the construction of first-class undergraduates with excellent style
}

\author{
Guangxi Xu, Xia Mingliang
}

Shaanxi Normal University 710119 xugx@snnu.edu.cn

\begin{abstract}
Based on the foundation, four returns" is the guiding principle of undergraduate education that universities can refer to when adapting to the current social development pace in the new era. Under the guidance of this new education and teaching concept, major universities have gradually deepened their awareness of modern high-quality and high-level talent training, and consciously reformed and optimized their actual teaching goals and teaching methods used. In this way, the quality of undergraduate talent development can be improved comprehensively and efficiently.

Keywords: Based on the foundation; four regressions; excellent style of study; undergraduate construction

With the continuous development and progress of the economy and society, the demand for modern talents in all walks of life has gradually increased, and the corresponding assessment requirements have also increased accordingly. As an important output place for social talents, colleges and universities should correctly recognize the importance of their own development status and the significance of talent quality in promoting the progress of the industry. They should keep up with the pace of development of the times and use the emerging concepts issued by relevant departments as guidelines. Gradually build a scientific and reasonable management system, and vigorously promote the efficient implementation of a series of undergraduate construction activities. Especially for the optimization of the style of study, this is the key to each university's entry into the first-class field, and it is also an important factor that actually affects its overall development strength. Therefore, it is of great practical significance for colleges and universities to regard "this as the foundation, four returns" as a guide for the construction of first-class undergraduates.
\end{abstract}

\section{The connotation of "based on this"}

Colleges and universities are important bases for the export of modern talents and serving the society, and their actual teaching quality and efficiency are closely related to the level of social talents. Therefore, the education management department puts forward when guiding the undergraduate colleges and universities to carry out a series of construction activities, "talent training is the foundation, and undergraduate education is the root". If major colleges and universities want to enter the ranks of first-class undergraduate colleges and universities, they should make effective work in the cultivation of high-quality and high-level talents, and shoulder the mission of education and education given by the times, so that they can better integrate with science and education and the country. Development strategies such as strengthening the country with talents echo. The actual connotation of "based on this" is to effectively consolidate the fundamental position of undergraduate teaching in the process of talent training, and use this as the basis for various education and teaching activities to help modern talents consolidate their own development foundation.

\section{The connotation of "four regressions"}

The "Four Regressions" put forward is a fundamental criterion for testing the quality and final effect of talent training in various universities, and has certain reference value. The "four returns" refer to returning to common sense, returning

Copyright (C) 2020 Guangxi Xu et al.

doi: $10.18282 /$ le.v9i5.1218

This is an open-access article distributed under the terms of the Creative Commons Attribution Non-Commercial License

(http://creativecommons.org/licenses/by-nc/4.0/), which permits unrestricted non-commercial use, distribution, and reproduction in any medium, provided the original work is properly cited. 
to duty, returning to original intentions, and returning to dreams. Returning to common sense requires educators to carry out educational activities around students' actual learning, guide students to actively explore knowledge and master true skills, so that they can build their own connotations in an orderly manner under the guidance of learning interests, and optimize the final learning results. Returning to duty is from the perspective of education, requiring teachers to correct their teaching attitudes, love education, devote themselves to teaching and educating people, strictly regulate their own ethics and style, and lead by example to inspire students to learn actively. Returning to the original aspiration is for students to have a comprehensive and objective understanding of the current situation of political and social development, and correctly grasp the direction of political development, so that their scientific and cultural knowledge learning and political ideological upgrading can progress simultaneously, thereby enhancing their own comprehensive development strength. And returning to dreams means that teachers break through the shackles of traditional teaching concepts, promote the orderly development of organizational teaching activities, system management content innovation activities, and targeted help students to deeply understand the connotation of the Chinese Dream, and strive to serve the country with education and study to serve the country. .

\section{Specific and effective measures to build a good academic atmosphere}

\subsection{Improve the teaching level of teachers and optimize the actual education effect}

As the core organizer of a series of educational and teaching activities, teachers, their own comprehensive quality level and development strength are related to the final actual teaching effect to a certain extent. Especially for undergraduate education, undergraduate students' thinking system is relatively well developed, and they have a unique way of thinking. If they blindly instill compulsory education knowledge, they may trigger their rebellious psychology to a certain extent. Conducive to the efficient development of follow-up series of education and teaching activities. Therefore, in order to build a first-class academic development level, undergraduate colleges should first carry out teaching concept innovation activities for teachers to help them correctly recognize the new trend of talent training in modern society, and then make targeted education and teaching activities of their own. Innovation and optimization. Teachers can also introduce new knowledge and adopt new teaching management models according to the specific needs of training activities, realize modern diversified teaching innovation, and comprehensively promote the overall development of talents.

\subsection{Create a good learning atmosphere and highlight the importance of building a style of study}

The learning environment is the background for students to participate in learning. The quality of its environment affects the actual learning situation of students to varying degrees. Therefore, all undergraduate colleges and universities should be aware of the importance of creating a learning atmosphere when carrying out activities to build a good academic atmosphere, and use this as an entry point to gradually consolidate the foundation for the optimization of the overall learning environment. Undergraduate colleges and universities can set up learning seminars, lectures, professional competitions and other activities according to the social development status and the actual learning situation of students, which can effectively enrich the content of students' knowledge system, strengthen its fundamental development connotation, and fundamentally help them cultivate their good Learning awareness and learning habits. In addition, the school can also increase the reward and punishment system accordingly to stimulate students' interest in learning and inquiry, highlight the key significance of the construction indicators of the academic style to the overall development of students, and make students aware of the impact of their own learning on the school's academic atmosphere, or in the excellent academic atmosphere Under the guidance of the students, correct their own learning habits and achieve overall progress.

\section{Concluding remarks}

In summary, "based on this, four regressions" is the key to guiding the orderly development and progress of education and teaching activities of undergraduate colleges in the new era, and it is also the basis for guiding them 
to achieve innovation and progress. Therefore, when colleges and universities are building a good style of study and improving their own development level, they should optimize and innovate their own actual management system based on the specific content of "based on this, four regressions", and then vigorously consolidate their overall development strength.

\section{References}

1. Zhang Zhimin. Adhere to the "base-oriented" and strive to create a first-class undergraduate professional constructionSichuan University teaching training experience and experience $[\mathrm{J}]$. Modern Distance Education of Chinese Medicine, 2020, 18(02): 158-160.

2. Song Yubin. Analysis of measures to strengthen the construction of academic atmosphere in universities under the background of promoting the "four regressions"__ Taking the School of Electrical and Control Engineering of Heilongjiang University of Science and Technology as an example [J]. Journal of Ankang University, 2019, 31(05): 116-119.

3. Yang Ruixue. In-depth study and implementation of Xi Jinping's important speech on "Based on the Foundation" and "Four Regressions" to reflect on the misunderstandings in the social practice of colleges and universities-Taking the Department of Social Work of Inner Mongolia Normal University as an example[J].Western China Quality Education, 2019, 5(10): 65-67.

4. Li Yuji. Adhere to the "base oriented" and promote the "four regressions" to cultivate talents in the new era of morality and law concurrently with the rule of law-based on the exploration of Gansu University of Political Science and Law [J]. Law Education Research, 2019, 25(02): 126-138. 